\title{
RE-VISIONING WOMEN IN TWO FOLK TALES BY A WOMAN NARRATOR
}

\author{
Noriah Taslim \\ tnoriah@gmail.com
}

Faculty of Arts and Social Sciences

Universiti Brunei Darussalam

\begin{abstract}
The paper is an attempt to read two tales about women by a woman narrator with an underlying assumption that only a woman could possibly represent a more authentic female life, and thus her story about women would invariably repudiate other so-called "untrue" formulations about women. With that as a premise, the paper would proceed to unfold the re-imagining or rather the re-visioning of women in the two tales; and this would demand, so to speak, a more unconventional critical method of analysis (benefiting in many ways the feminist strategy of reading) to discover the technique and strategy of repositioning the women characters in the two tales. The paper concludes with two rather uneasy propositions: the texts do give a refreshing presentation of female power in an environment of male hegemony, but the powerful women are not in any way a threat to the patriarchy; as a matter of fact, they help uphold the patriarchal order of things.
\end{abstract}

Keywords: folk tales, re-visioning women character, female power, male hegemony, feminist reading strategy

\section{INTRODUCTION}

\author{
If I am lonely \\ it must be the loneliness \\ of waking first, of breathing \\ dawn's first cold breath on the city \\ of being the one awake \\ in a house wrapped in sleep
}

(Adrienne Rich) 
The paper endeavors to study two tales about women as narrated by a woman narrator. The underlying assumption of this study is that only a woman could possibly represent a more authentic female life, and thus her story about women would invariably repudiate other so-called "untrue" construction of women. With that as a premise, the paper would proceed to unfold the re-imagining or rather the re-visioning of women in the two tales. And this would demand, so to speak, a more unconventional reading method; and in compliance, I have chosen to appropriate in many ways the feminist reading strategy to uncover the technique and strategy employed by the narrator to re-position the women characters in the two tales. To facilitate analysis and to familiarize the reader with the tales and the narrator, the paper would begin with a summary of the two tales and a brief narration about the narrator.

\section{SUMMARY OF THE TEXTS}

\section{Text I The Story of the Mouse Princess}

Once, there was a king who had three handsome sons. All the sons were ambitious and competed for the throne, except for the third and youngest son. He had no desire for the throne and thus he chose to live outside the palace. What he loved most was to roam the jungle and hunt animals. One day, he found a white mouse in his trap; fascinated with the beautiful mouse, he took the mouse home to be his pet.

When he reached a marriageable age, the king and queen wanted him to choose a bride, for his two brothers had already chosen beautiful brides for themselves. One day he sat sadly next to the white mouse and told it his problem. To his surprise, the mouse spoke to him; it told him to inform the palace that he had already found a bride. The prince followed its advice and the parents were overjoyed. A wedding feast for the three sons was prepared. Before the wedding, the queen wanted to see the bride of the youngest son; the prince rushed home and told the mouse that he was in deep trouble because his mother wanted to see the bride. But the mouse said not to worry, and asked him to tell the palace that the bride was menstruating (uzur) (in menstruation) and could not leave her palace until after seven days.

Hearing that, the queen felt suspicious and told the prince if that was the case, then she wanted the bride to help in the preparation of the feast. The next day she sent in loads of paddy grains to be husked by the bride. The prince was very worried, he feared that the mouse, being so tiny would 
never be able to perform the task. But the mouse promised him that the task would be done by the next morning. That night she summoned all the rats in the land and in less than a night, all the paddy grains were cleaned of their husks.

The next day, the queen sent in sacks of flour; the bride was asked to bake cakes (kuih bakar) for the feast. Again, the prince was worried; this time he said, their secret would surely be revealed and he would be in deep trouble. But the white mouse promised him that the task would be done by morning.

That night, again she summoned all the rats in the land and they started baking trays and trays of cakes. Just before morning, while the white mouse was oiling the baking tray with its tail, the tail caught fire and so was the rest of the body; then amazingly a beautiful woman emerged from the body. Apparently she was a princess who assumed the form of a white mouse. When the rest of the rats realized what had happened, they quickly rushed out of the house. The princess quickly hid herself in the room.

When day came, the prince came looking for the white mouse and saw all the cakes were ready for the feast but the mouse was no where to be seen. He entered a room and saw a strange, beautiful woman there and everything was then explained.

After seven days, the prince brought his beautiful bride to the palace. Everyone was amazed because she was more beautiful than the other two brides. The wedding went on as planned and things returned to its normal routine. But the two brothers were so captivated by the beauty of the youngest brother's bride that they could not neither sleep nor eat in peace. Finally, unable to contain their yearnings, the two brothers confessed to each other and agreed to compete for the princess. The truce was the one that could win her affection would take over the throne.

First, they had to get the youngest brother out of the country. They persuaded the king to send the youngest son as an emissary to a nearby country to settle a longstanding war between the two states. The king agreed and the youngest son was assigned with the task.

Soon after he left, the second brother went to his house, knocked on the door and pretended that he came to check on the brother's wife, since the husband was away. She invited him in and he stayed on until almost evening; he was then served dinner and soon began to make advances to her. She told him to wait for her in the room, while she prepared herself. Thinking that he was going to have his desires fulfilled, he entered the room 
and waited. After a while she came in, brought with her drinks and asked him to relax while she entertained him. Apparently she had spiked the drink, and before he even realized it, he was fast asleep. She quickly locked the door from outside.

The next day, the first brother was anxious to know what had happened. He went to his second brother's house but was told that he had not been home from the other day. Curious, he went home; dressed himself in his best attire and went to his youngest brother's house. Similarly, he was very well-received and entertained; later on, he too was tricked to wait for her in another room, and had his drink spiked and fell into a very deep slumber.

On the third day, the youngest prince came back from the mission; he went straight home to his waiting wife. Meanwhile, the two brothers knowing that the youngest brother had come home, pleaded to be released. She agreed, but first they had to disguise as maids; she then dressed them as serving maids and made them wait upon her husband at the dinner table. While serving, one of the brothers nervously spilt drink on the brother's hand, while the other spilt soup on his chest. He scolded them for being clumsy and was about to punish them when he recognised the rings on their fingers. They were forced to come out of their disguises, and after apologizing profusely, they were taken before the king. The king banished the two brothers from the country and the youngest brother was appointed to the throne and upon advice from the king, his wife was appointed as his advisor (wazir).

\section{Text II The Story of Cik Wi (Ceciwi)}

Once upon a time, a princess set sail to marry a prince in China. On the way, her ship met with a huge storm, all her crews perished, except for her maid called Cik Wi. Now this Cik Wi was a girl from the hinterland tribe (the informant called her orang darat or sakai). They then continued their journey until they reached a river and the princess decided to stop to have a bath. She took off all her fine clothes and jewellery and went into the water to bathe. Meanwhile, Cik Wi had decided to fool the princess; she took off her own shabby clothes, wore the princess's dress and adorned herself with her fine jewellery, and later when the princess asked her to return her clothes, Cik Wi threatened the princess and forced her to put on the shabby clothes. Thus, they continued with the journey upstream. After a while, news about the princess's arrival reached the palace. The prince sent people to the river to welcome the princess. Deceived by her fine attire, they mounted Cik Wi 
on an elephant and accompanied her to the palace where she received a grand reception. A wedding was held and Cik Wi lived in the palace as the wife of the prince. However, she betrayed her lowly upbringing by her uncouth behavior: she spoke in a coarse language (curious dialect); she slept on the floor instead of on the bed; she ate greedily and noisily; she had several bad habits which disgusted the palace maids (like riding on a pig instead of an elephant). Meanwhile, the real princess was forced to live in the servant quarters under the palace, and she had to do chores for her meals. To support herself, she planted paddies next to the royal rice field. When the paddy plants started to fill their seeds, she had to guard them against birds and rats. While chasing the birds, she started to sing:
Birds o birds!
Do not eat my paddies
Go eat the king's paddies
For the king's a fool
Cik Wi was taken as the princess
And the princess as Cik Wi!

And she chased the birds away towards the king's paddy field. The next day, rats started to come and ate the ripened paddies; again she chased the rats and started to sing:
Rats, o rats!
Do not eat my paddies
Go eat the king's paddies
For the king's blind
Cik Wi was taken as the princess
And the princess as Cik Wi!

\begin{abstract}
And again, she chased away the rats towards the king's rice field. Now, the caretaker of the king's paddy field overheard her songs, and was angry because birds and rats started to destroy the royal paddy field. He went back to the palace and reported the matter to the prince. The next day the prince himself came to the field and heard her singing and saw what happened. He approached the princess and demanded an explanation. The princess told him the truth; the prince realized his mistake and she was then taken back to the palace. She scrubbed and bathed in fragrant water (mandi berlimau)
\end{abstract}


and then dressed in the finest of clothings and presented herself before the prince. He was immediately struck by her beauty and grace, and realized that she was the true princess. Meanwhile, Cik Wi was stripped off her fine attire and her true self was revealed.

Once in the palace, the princess summoned the ministers to arrest Cik Wi and brought the imposter to her. Cik Wi menwhile, had swallowed an earthen jar (tempayan) to make her look as if she was pregnant. And when she was dragged to the princess she screamed saying that she was pregnant with the prince's child. The princess, cut open her stomach and found an earthen jar. She then cut up her body, pickled it in the earthen jar, and sent it back to her parents in the jungle.

\section{Text III Story of the Narrator}

The summaries were based on texts collected during my undergraduate field research in 1974; the stories were narrated by Naemah Sabirin (19141987), a storyteller from a remote village in Kedah. In the village, besides other things, Naemah taught Qur'an and some basic aspects of Islam (to children as well as women) and sometimes tell them stories to while the time. She herself hailed from a small settlement in Butterworth; due to some unfortunate circumstances in her early teens (when she was 11, her mother had a mental breakdown; she had to take care of her young siblings, then her father remarried and she was sent to live with a relative), she was forced by her father to marry a rich old man thrice her age (she was 15); she then had to move to another town (Kupang, Baling) and lived with the husband's family. All those time, she suffered abuses from her stepmother in-law (which included tests on her domestic skills) and sexual harassments from her step son. But she stood firm with her marriage. Finally, through devious means, the two succeeded in persuading her husband to remove her from his will. She later found out about the dubious will and asked for a divorce; after a bitter fight with her husband (who refused to divorce her), she finally got her divorce and to avoid further advances from her husband, she took refuge in the home of a distant aunt who lived in the village. Life with this aunt was also merciless. Her aunt had an ailing husband and she was the only breadwinner. To help make ends meet, Naemah had to do endless chores and errands; and all the while she faced her life bravely. After refusing several offers of marriage, she finally agreed to be married to a farmer, himself a widow with three young children. She willingly took 
over the role as a mother to the young children while helping her husband to work on the fields. From the second marriage, she had two children of her own-a boy and a girl. And from the little knowledge and exposure she got while living "outside" the village, she raised the children to be better than what was expected of village or peasant children. They both went through college and university and later held respectable government posts.

\section{READING THE NARRATOR}

I purposely detailed her life-story to highlight the strength and uniqueness of this woman. She fought adversaries that threatened her marriage, she refused to be a victim of the seditious in-laws, retaliated against unfairness, and fought for her independence and self-respect. Later, although she suffered mentally and physically, she did not succumb to her circumstances; she only gave herself a second chance in marriage when she felt she was ready and the man himself was worthy of her. Within her limited resources, she raised her children to be better than their fore fathers.

She had been the victim of man's power and oppression (the forced marriage, the sexual harassment, and in fact her initial silence itself was a form of male subordination); biases towards women were very much the practice at the turn of the century. Her life story reinforces the view that women inhabit the margins of power. But it was this life experience that taught an important lesson to this woman-that a silent woman had little opportunity to defy subjugation. Thus, her marginality is in fact empowering instead of crippling her. In her capacity as a wife or woman, she acted to correct the injustice (of her husband) and end the patriarchal rule and thus finally found her own freedom; although the new life was no bed of roses but it was the life she chose. At last she found herself and claimed her worthiness as an active functioning individual.

Her narratives about women, in many ways, epitomized her experience as a woman. We seriously believe that the narrator's experience and her various nurturing have a certain bearing on her imagination and creativity or what we may term as the psychodynamic of creativity. Apparently we also have to agree with many literary sociologists' views (Pierre Machery, 1986 and Janet Wolff, 2006)) that "writing is a situated practice" and "an author is a located individual". Thus, we cannot separate the narrator from her social, cultural and personal identity. We may also have to favor the views of some feminist critics (Adrienne Munich, 1985) that as a female, her stories about 
women are more authentic (although I also accept the fact that this word can be problematic; texts or discourses are always mediated by ideology as such they were always aligned) than male's. Feminists believe that male authors could not speak truly about women, that men lie about women to mythologise and to create ideals (I have discussed the issues about the (mis) representation of women in Malay traditional literature in other essays, see Dewan Sastera, May-August, 2011).

\section{READING THE TEXTS}

For a feminist, (Adrienne Munich, 1988:124) this recovering of texts by women and studying texts that express women's experience (labelled by some as gynocriticism) would be a good opportunity to:

... set the record straight, to correct the (gender) imbalance and to restore critical attention to authentic female voice.

In many societies, folk tales were known to be used as a corrective measure or avenue of correcting social imbalance, gender included. The Joke lore, for example, more so than any other folk genres, is the best medium of social critics (see Noriah Taslim, 2007 for a comprehensive analysis of joke lore as medium to deconstruct social taboos, power and hierarchy). Using what theorists (Mc Ghee, in Wilson, 1979:15) called the joke frame or the play frame, a joke "conceals malice and allows expression of aggression without the consequences of overt behaviour" (Stephenson, in Powell, 1988:245). Similarly, the fairy tale genre according to Margaret A. Mills (2001:238) can also provide "an alternative perspectives of the sexist, patriarchal point of view ..." Following this line of argument, this paper then, will view the fairy tale as an avenue of correcting gender imbalance and will attempt to read signs of female power inscribed within.

The reading of the texts is also preceded by the premise that reading like writing is always aligned, never truly objective. Although I am not a feminist (in the true sense) but I do subscribe to some of the feminists ideals and in my readings of the text I choose to appropriate some of the feminist critical reading strategies. Thus my approach and interpretation are inclined to be what the feminist critics termed as "revolutionary" (see Josephine Donovan, 1989) and "revisionary" (see Adrienne Munich, 1988).

The first tale (the Story of the Mouse Princess) that I scrutinize brings 
up the theme of a woman's struggle to be in control of herself, her desires and her situation or predicament in an oppressive feudal, patriarchal setting. To accentuate her struggle and her active participation in the plot, the text sidelines the male character (the prince) and downplays his involvement in the plot.

The text in its initial stage weaves stories about the awkward relationship between a human prince and a female mouse (a princess under a spell) as metaphor for a complex and somewhat ambivalent relationship of a "woman" to the patriarchy and the dominant culture.

Her appearance as a "mouse" itself is a metaphor for her physical deformity imbued with the female stereotypes-weak, powerless, inferior, domestic, uncultured (animal), a play or pleasure object (the mouse as pet)-constructed and prescribed by the patriarchal culture (see the binary oppositions that structure the patriarchal system mapped up by Helene Cixous, in Ann Rosalind Jones, 1988:82). Similar to the mouse, she is constrained not only by her physical nature but also confined by her role and space (domestic), and time (mouse is a night creature, woman is also associated with night; see the gender categories by Helene Cixous, 82).

However, a revisionary reading of the text reveals that this woman is allowed to wield more power than what is apparent; her deformity, roles and space which appear constrictive are in fact enabling and empowering. She exploits these and her female biology to gain control not only her object of desire (the prince) but also her state of being (concealing herself as a mouse) and her predicament (the queen's or feudal oppression).

Thus, when she is summoned to present herself at the court for the queen to view or rather appraise, she uses her natural bodily functionmenstruation, to evade revealing her identity and risk losing the prince. This is interesting to note especially in a text contained in a conventional frame. Menstruation is taboo in the Malay traditional society, you are not allowed to talk freely about it, it is shameful and secretive; folks would use other names or metaphors such as datang bulan (the moon has come) kawan baik (best friend), datang kotor (the dirt has come) to avoid being straight forward. Menstruation is always associated with the so-called woman's "affliction' or "deformity"; a menstruating woman is unclean, ailing (uzur), segregated and immobilized.

With the traditional notions about menstruation, it is aptly used here as a strategy of self-defence, and as an excuse from blame. The (mouse) princess, appropriates her "deformity" and the taboo which in normal 
situation is discriminative to a woman, to defy the feudal order as well as to have control of the prince.

Her cunning scheme, however, brings new threats to her identity; the queen grows suspicious and gives her domestic tasks to perform as tests of her domestic skills. The first task requires to unhusk sacks of paddy grains; the second, she is asked to bake cakes (kuih bakar), both for the upcoming wedding. Again she appropriates her "physical deformity" (as a mouse) and the confines of her space and time to complete the task. She summons her subjects (mouse) to help gnaw the paddy husk which incidentally is what a mouse do best. To avoid detection from the prince and thus risked revealing her disguise, she has to perform the job at night. Again, this strategy suits well with the natural behaviour of the mouse as a nocturnal animal.

The next task too is uncomplicated; again she uses her "mouse" skill to handle a large amount of flour, her little tail replaces the brush to oil the baking tray, her little hands shape the biscuits perfectly. And similarly the jobs have to be secretive, carried out at night and luckily for her everything seems to go perfectly as she planned, until an accident happened. The princess burns her tail while oiling the baking tray, and so also is her mouse skin. The spell is broken and her real identity is revealed.

Now this is not just a turning point in the plot, but a strategic device to safeguard her credibility (her seven-day grace period is over), avoid punishment and allows her to mature or transform into an authentic woman that would then enable her to impose her right on the prince and claim a reputable position as his chosen bride. By transforming from a mouse to a woman, she experiences a vertical mobility that allows her the right to claim a position along side a male character, in fact higher (for the male character is shown to be dormant and passive). And by her various feats of overcoming obstacles, she is also repositioned in the plot as a subject or actor instead of object or passive participant, similar to other conventional texts.

The next stage of the plot is the perfection or completion of her potential womanhood as aspired by the narrator. The woman character here is allowed to grow from just being a woman who is in control of her life, to some one who takes control over men's life, manipulates them to bring justice, correct the abuse of power and radically changes the feudal and the social order. She is here empowered to transform the social world in a more radical way than ever imagined in other circumstances (in fantasy or otherwise).

In this second stage of the story, the woman character or princess is placed in a new predicament which threatens to undermine her integrity 
and security of her marriage. Again, as is the case with women living in a man's world, it is her physical appearance that brings problems into her life. This time it is her beauty. Beauty to a woman is both an asset and a liability. In many traditional texts, the beauty of women turns them into objects of desire, love or hate. Men and nations have fought one another to possess such women; jealous wives and in-laws have victimized and tortured her; they have to be hidden from male gaze, kept away in high castle, wooden chests, magic caskets and huge shells. A beautiful woman is cut off from society, left alone and suffered loneliness (see Noriah Taslim Dewan Sastera May-August 2011, for a comprehensive analysis of women's predicament in men's world).

In this tale, the theme of women's beauty again prevails. The princess's beauty as always has similar entrancing effect on men. When the two elder brothers catch sight of her extraordinary beauty, they fall insanely in love (the Malay term for it is gila berangta); the text describes their pathetic situation as shown below:

\section{Makan tak kenyang \\ Tidur tak lena \\ Mandi tak basah \\ (They eat but remain hungry \\ They sleep but remain awake \\ They bathe but remain dry)}

Being in such an importunate state they would risk anything (even losing the throne) to possess her (sexually). She is now placed in a precarious situation, reduced to the men's object of desire, similar to other rare objects that men aspire to possess such as a "treasure chest", the flower of life, and magical stones. To compete for her "body", the brothers enter into a truce, whoever can possess her will gain the throne (for both of them also compete for the throne).

She is now pulled into the brothers' power game, placed as an object of competition; the winner will be rewarded not only with her "body", but also power, status and wealth-the complete package of the men's dream. With the lucrative prize in mind, the two brothers eagerly begin the game, but first the husband has to be removed from the premise; without her husband she would be defenceless and vulnerable. Then comes the courtesy call; on the pretext of checking on her welfare while the husband is away, the brothers (they come separately, one after the other) knock on her door, enter into the 
privacy of her home, enjoy her lavish food and company, linger until late in the evening; and taking advantage of her seeming naivety, start making sexual advances on her.

Meanwhile, the woman has the privilege of what feminists call "female intuition" (see Adrienne Munich, 1988). For some feminists the term is quite pejorative in a sense that it denotes extra-rational knowledge thus, it goes well with the stereotype that categorises the female intuition as not rational. She is quick to sense the real motive of the men, and is well-prepared to handle their "game". She takes full advantage of her admirer's intoxication with her beauty and their male gluttony for food to entrap them. She skillfully exploits their weakness for her benefit. Employing her own social and domestic skills (she serves them delicious food, rest them in a comfortable bedroom); she manipulates the unsuspecting brothers and slyly manages to restrain their sexual advances on her.

Once again, we witness the invisible power of a woman being brought to the fore. She fights back her potential oppressors using to her advantage her biological and culturally prescribed attributes of (beauty, nurturing, domesticated). In her further attempt to delude them and as a strategy to take full control, she switches herself from a potential victim or prize to a pseudo-ally. What she does is actually a smart female move, she seduces them into believing that she is a willing partner and when they are completely deluded, she does what any woman in her situation (defenceless against her more strong oppressors) would do, spikes their drinks, locks them in the room and thus immobilizes them. The woman shows an incredible ability to manage her own space (domestic space) for her immediate defense. She has overturned their despicable attempt to make her as their object of desire, as a trophy to be won in the competition.

What she does next is rather unprecedented and radical. When her husband returns, the brothers beg her to release them and promise that they would do anything to escape being found by her husband. She complies but not after she humiliates and punishes them by transforming them at least temporarily into her domestic maids. They are made to wear female clothes and to complete the gender transfer, they also had to do domestic chores-serving food at the table, the role normally assigned to women. We can imagine how ridiculous and pathetic the two court elites appear at the dinner table. They are later made to suffer further embarrassment when their identities are finally revealed to the husband. 
The woman as victim and executer of justice has succeeded in undermining not only their masculinity, but their status and stature as members of the court. As it is, the text offers a fresh perspective in its handling of women's predicament in a world dominated by men. The story then ends with a good poetic justice. The brothers are banished from the kingdom and the youngest son gets the throne; his wife subsequently is appointed his advisor, a post normally held by men-a departure from tradition which resonates new possibilities for women. She has, after all, succeeded in broadening men's perspective towards a woman's potentials and capabilities.

The second story (Cerita Cik Wi) brings to the fore the theme of victimized women-a common and typical theme, running through most folk or court romance. In many stories (the authors are anonymous but all subscribed to the dominant patriarchal ideologies, see Noriah Taslim Dewan Sastera MayOgos, 2011) - Syair Selindang Delima, Syair Bidasari, syair Ken Tambuhan, women through no fault of their own were captivated, enslaved, abused and some were even ordered to be killed. And their enemies surprisingly were all women-the jealous wife, evil queen, cruel mother in-law.

These women, true to their respective cultural stereotypes, were submissive, accepted their fate and suffered silently; they were given voices but only to cry, to question their wretchedness and beg for mercy but none were given the strength or the resources to fight back. And following the ideal schema of the plot, these victimized women were later rescued by a gallant and mighty hero who then married them as reward for saving the helpless women. As a consequence, they live happily ever after. Such stories perpetuate the gender bias of patriarchal culture and the portrayals of women which reinforce women's weaknesses and justifies men's subordination over them.

The Story of Cik Wi deals with the similar predicament of women, but differently; it opposes the positioning of female-male roles and breaks away from the conventional stereotype to offer new gender perspectives and possibilities. As the story goes, she (the princess) is victimized by her maid (Cik Wi) who takes over her place and deprives her of her right to marry the prince. Dressed in rags, she is mistaken as a commoner or maid and forced to live in the servant's quarters. To complete the process of degradation, she also has to do the servant's chores to obtain her food.

Themes of women being victimized, disabled and immobilized are reflective of female roles in most texts which place women as: "not actors but mere subjects of male action and female biology" (Gayle Greene, 
1986:16). The ideological function of placing women in such a role and state is to legitimize their dependence on men, relegating them to a more inferior position.

Nevertheless, in this text, the victimized woman is made to resist the gender stereotype; far from being disabled and immobilized, she is given practical strategies to break free from the oppressive situation that threaten to deprive her of her autonomy. Instead of succumbing to the dominant power, she challenges it and later not only she punishes the victim but also subverts male authority. By her behaviour, she falls outside the prescribed gender roles and the text finally offers a refreshing image of a female character.

Let us now see how the narrator empowers her. Her first move is to secure her economic independence; she is not going to live on the mercy and charity of the palace. She decides to grow her own food, by doing this she transgresses boundaries of her female roles and domestic space to assume men's economic function. And she does this very well; her paddy field flourishes and now waits to be harvested. But she also plans a strategy of counter attack of her oppressors-the palace. What she does is amazingly brilliant; to facilitate her counter-attack she grows her paddies just adjacent to the palace's rice field.

While waiting for the paddies to ripen, she has to watch for the birds and rats that come to feed on the young seeds. Aware that the king's paddies also ripen at the same time, and there are people of the palace tending to the fields, she resorts to attract their attention by singing and then chasing the birds and rats towards the palace's rice field so they would feed on the king's paddies. And as she has planned, she does attract the palace; the king himself comes to witness her offensive act.

The first thing he hears is her songs; now the princess does not sing love song (as youths normally do), but songs with lyrics that are subversive and intended to deride the king and ridicule the charade that is going on in the court. Let me recall a few lines from the songs:

\author{
Song I \\ . \\ For the king is a fool \\ Cik Wi is taken as the princess \\ And the princess as Cik Wi
}




\section{Song II}

...

For the king is blind

Cik Wi is taken as the princess

And the princess as Cik Wi

The songs blatantly criticise the king-that he is a fool, as well as blind (figuratively). Only a fool can be easily deceived and mocked at; and only a blind person fails to differentiate between illusion and reality, apparent and truth, form and essence. The critique is also directed towards most men, who normally judge women by their form and body (see also the episode in the story where the king only believes that she is a princess after seeing her in her fine attire). The king, like most men, is deluded by form and superficiality and allows his sentiment and misjudgment to cloud his reason. Through his failure to comprehend reality and truth, he has unwittingly made a mockery of himself and the whole credibility of the feudal institution. And the fact that all this is done by a woman, not any woman but a woman (a maid) of such inferior and dubious origin, is really subversive.

The songs in just a few lines become a potent medium of resistance. Through them (besides her physical act of chasing the birds and rats into the palace rice field), the princess shows her defiance which in feudal culture can cost her life and honour. But on the contrary, she manages to put sense into the king's head, transforms him and the social condition of the court; and more importantly, succeeds in claiming what is her right (the prince as her husband).

Her next strategic move is also spectacular. She has to win the king's love to take possession of him. She adorns herself in the finest of clothes and presents her "new" self before the king and as she has expected, the king is completely infatuated by her beauty and grace and unhesitatingly, accepts her as the true princess. After regaining her possession and position, she now acts on her own capacity to bring justice to the villain herself. In most literature, the execution of justice normally falls under man's jurisdiction; in fact according to Gayle Green (1988:24) "the idea of justice itself is masculine". But here, she is given the privilege to punish the villain, and by her act she rescues the palace from chaos inflicted by the villain and restores the court's harmony which, in most folk romance is the task and responsibility of the hero (Noriah Taslim, 1996). By assuming the role of the hero, she has overturned the female stereotype, and breaks free from her conservative mould. 


\section{CONCLUSION}

The two stories can be seen as an avenue to critique and correct abuse of power. The texts do give a refreshing perspective of female roles and power in a world dominated by men. They both reflect the narrator's belief that women can exert changes (in fact wield more power than what is apparent) and that their social constraint, in fact, can be enabling and empowering.

The analysis follows the assertion that the narrator's experience and her social conditioning in patriarchal culture can be found inscribed in the stories. We can trace the similarities between her life and those characters in her story.

Such stories, (according to Gayle Greene, 1988:16): "are subversive in a sense that they propose change in perspective in the gender relation in society. They provide practical strategies for coping with problems of the sort many of them might well be facing in man's world".

However, the female narrator (like most female authors) cannot really escape from the conventional frame, and her identification with the dominant culture has to a certain extent dominate her imagination. She may be seen to subscribe to nontraditional values but this is very much in accordance with the cultural ideals of the time, within the situation allowed by institutional authority-Islam being one of them.

The women characters in her stories still serve patriarchy, their participation or dominance continually recreate the prestige of their husbands; for example, the princess, in the Story of the Mouse Princess, helps her husband to gain the throne and help perpetuate male power, she later dominates the brothers or oppressors, so she could preserve her virtue as a wife. Her appointment as a "vizier" probably is an acknowledgement of her credibility but ironically, the position pushes her further into the feudal structures.

Similarly, the princess in the Story of Cik Wi poses a woman as the villain; while in fact the king should bear the blame for her misery. While she should punish the king for his arbitrariness in dealing with the situation, she seeks his recognition and acceptance. She is given power but can only act with the backing of the feudal court. In her role as a hero, she inadvertently helps restore the feudal order.

In conclusion, the women in the stories are not oppositional to men and patriarchy, they only oppose the oppression and the injustice in the system. The narrator herself was circumscribed by culture and tradition; she 
herself did not oppose her prescribed gender roles and biological function as nurturer or wife (she took over the roles of mothering her step children, she gave birth and nurtured her own off-spring) and as a wife. As I see it, in furthering their course, women need not neglect their biological roles. They, however, should be allowed to grow to their full potential and not seen as an adjunct to men or as an inferior "part" of a male (or more pejorativelyan imperfect male) as constructed by the cultural myth. Her relationship to men should then be complementary, not binary.

\section{REFERENCES}

Crisp, Jane et al. (eds.), 2000. Deciphering Culture: Ordinary Curiosities and Subjective Narratives. London \& New York: Routledge \& Kegan Paul.

Donovan, Josephine (ed.), 1989. Feminist Literary Criticism: Explorations in Theory. Kentucky: The University Press of Kentucky.

Green, Gayle \& Kahn, Coppelia (eds.), 1988. Making a Difference: Feminist literary Criticism. London \& New York: Routledge and Kegan Paul.

Holly, Marcia, 1989. "Consciousness and Authenticity: Towards a Feminist Aesthetic" in Josephine Donovan. London \& New York: Routledge and Kegan Paul.

Jones, Ann Rosalind, 1988. "Inscribing Femininity: French Theories Of the Feminine" in Gayle Green. London \& New York: Routledge and Kegan Paul.

Kaplan, Sydney Janet, 1988. "Varieties of Feminist Criticism" in Gayle Green. London \& New York: Routledge and Kegan Paul.

Macherey, Pierre, 1986. A Theory of Literary Production. New York \& London: Routledge \& Kegan Paul.

Mill, Margaret, A., 2001 "The Gender of the Trick" in Asian Folklore Studies 60:2, Special Issued on Folklore of Iranian Region, John Perry (ed.) pp. 238-58.

Munich, Adrienne, 1988 "Notorious Signs: Feminist Criticism and Literary Tradition" in Gayle Green, \& Kahn, Coppelia (eds.). London \& New York: Routledge and Kegan Paul. 
Powell, Chris \& Paton, George, E.C. (eds.), 1988. Humour in Society: Resistance and Control. Hong Kong: The Macmillan Press Ltd.

Noriah Taslim, "Perpetuation of Tradition: Cosmic Myth, Courtly Culture and Structure of Space in Malay Folk Court Romance" in Jurnal Persuratan Melayu 2:1, 1996. Bangi: Universiti Kebangsaan Malaysia.

Noriah Taslim, "Gender dan Kuasa dalam Cerita Jenaka" in Jurnal Kultur Sept., 2007. Univ. Jember, Indonesia.

Noriah Taslim. "Cerita Tentang Wanita" in Dewan Sastera, May - August, 2011.

Warner, Marina, 1995. From the Beast to the Blonde: Fairy Tales and their Tellers. London: Vintage Book.

Wilson, Christopher, 1979. Jokes: Form, Content and Function. London: Academic Press. 